\title{
First record of Siganus randalli (Teleost, Siganidae) in New Caledonia, and comments on its diet
}

\author{
Thibaud Moleana ${ }^{1,34^{*}}$, Luc Della Patrona ${ }^{2}$, Tarik Meziane ${ }^{3}$ and Yves Letourneur $^{1}$
}

\begin{abstract}
Background: Most of the 29 Siganidae species are widely distributed through the Indo-Pacific area. In New Caledonia, these family was represented by 12 species. The present report is the first record of Siganus randalli in New Caledonian waters and provide information on its diet.

Methods: Three specimens of Siganus randalli were caught in shallow mangrove waters of the southern part of New Caledonia. Their stomach contents and isotopic signatures (carbon and nitrogen) were analyzed and compared to others siganids species.

Results and conclusion: This note provides the most southerly record of the rabbitfish Siganus randalli, which extends its distribution range by $1200 \mathrm{~km}$ southward and $1300 \mathrm{~km}$ southwest. The data on its diet, when compared with other co-occurring or more reef-associated siganid species, provide information on feeding processes and ecological functions associated with its mangrove habitat.

Keywords: Variegated rabbitfish, Diet, Stomach content, Isotope, SW pacific

Abbreviations: ADECAL, Agence de développement économique de la Nouvelle-Calédonie; ARR, Arrêté; C, Carbon; DENV, Direction de l'environnement; G, grams; IRI, Index of relative importance; LIVE, Laboratoire insulaire du vivant et de l'environnement; MM, millimeter; N, Nitrogen; SD, standard deviation; TL, Total length; UNC, Université de la Nouvelle-Calédonie
\end{abstract}

\section{Background}

Most of the 29 Siganidae species are widely distributed through the Indo-Pacific area (Woodland 1990; Randall and Kulbicki 2005). Their habitats range from estuaries and mangroves to outer reefs. This local distribution is closely related to their ecological function as browsers, croppers, mixed-feeders and spongivores (Hoey et al. 2013). In New Caledonia, 12 species have been recorded, though one of them needs further verification (S. vermiculatus; Fricke et al. 2011). Siganid species are currently identified by color and morphology characteristics such as snout shape, color patterns, body depth and caudal fin shape (Woodland 1990; Randall and Kulbicki 2005;

\footnotetext{
*Correspondence: t.moleana@gmail.com

'Laboratoire LIVE et LABEX « Corail », Université de la Nouvelle-Calédonie, BP R4, Nouméa 98851, New Caledonia

${ }^{3}$ UMR BOREA 7208, MNHN/CNRS/UPMC/RD, 61 rue Buffon, Paris Cedex 5 CP 53,75231 , France

Full list of author information is available at the end of the article
}

Borsa et al. 2007), but similarities in these characteristics between closely related species may lead to misidentification (Randall and Kulbicki 2005).

The variegated rabbitfish Siganus randalli (Woodland 1990) is a little known species and the information available mostly relates to aquaculture (Collins and Nelson 1993; Brown et al. 1994; Nelson and Wilkins 1994). It lives in brackish waters of mangroves (Collins and Nelson 1993; Nelson and Wilkins 1994), as well as above sandy bottoms of coral reef flats (Woodland 1990). The species is distributed widely from Guam (Kamikawa et al. 2015) and the Philippines archipelago (Galenzoga and Quiñones 2014) to Fiji (Blaber et al. 1993).

The aim of this paper is, firstly, to record the presence of Siganus randalli in New Caledonia and, secondly, to provide informations on its diet through an analysis of stomach contents and stable isotope signatures. The diet 


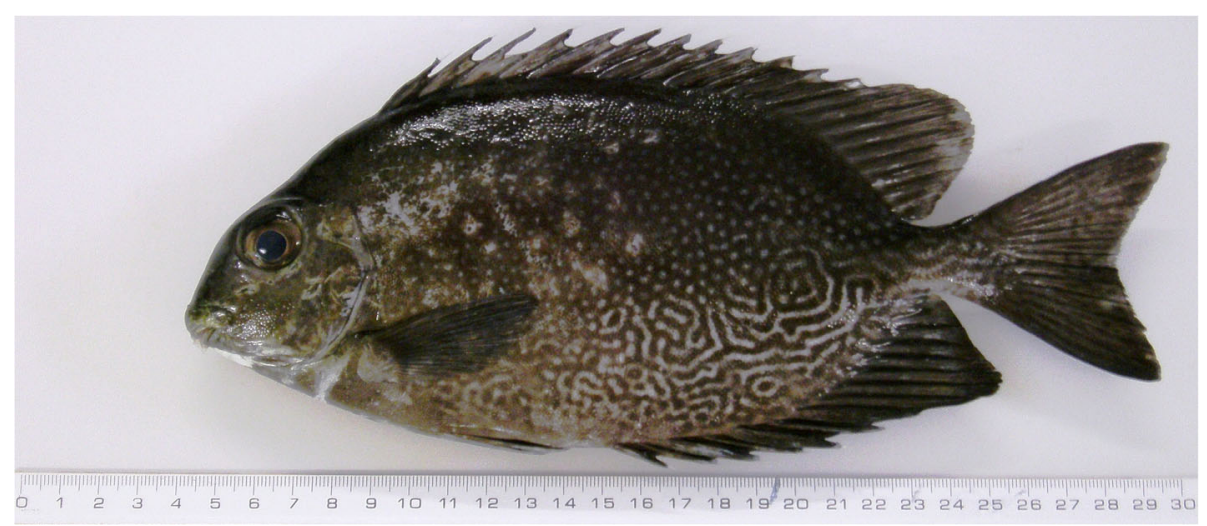

Fig. 1 Specimen (UNC-Y1002) of Siganus randalli caught during the experimental fishing session. Photo T. Moleana

data allow a better understanding of the functional role and habitat use of this species.

\section{Materials and methods}

On 5 March 2014, three specimens of Siganus randalli were collected (Fig. 1) at Goro $\left(22^{\circ} 17^{\prime} \mathrm{S}\right.$; $\left.167^{\circ} 1^{\prime} \mathrm{E}\right)$, southeast of New Caledonia. All specimens were caught with a gillnet in shallow mangrove waters $(0.5-1 \mathrm{~m}$ depth). Individual weights were measured to the nearest gram and total, fork and standard lengths and body depth were recorded to the nearest millimeter. In addition, three specimens of Siganus lineatus (Valenciennes, 1835) and two specimens of Siganus fuscescens (Houttuyn, 1782) were collected along with the three $S$. randalli, and were also analyzed for a comparison of diets.

Stomach contents were collected, weighed and preserved in a $4 \%$ formaldehyde solution. Stomach fullness was determined using the ratio between total stomach content weight and total fish weight. Each item found in the stomachs was then identified at the lowest taxonomic level and weighed. Occurrence (F\%) of items and proportions by number (N\%) and by weight (W\%) were monitored to estimate the Index of Relative Importance (IRI; Pinkas 1971) and express it as a percentage (\%IRI) of the total IRI of the stomach content. To ascertain feeding patterns, standardized niche breadth (B; Hurlbert 1978) and niche overlap (O; Pianka 1974) were determined using \%IRI of each item to take into account their occurrence and proportion by number and weight. Following Pinnegar and Polunin (1999), carbon and nitrogen stable isotope ratios $\left(\delta^{13} \mathrm{C}\right.$ and $\left.\delta^{15} \mathrm{~N}\right)$ were measured on dorsal white muscle of the jointly collected three $S$. randalli, two $S$. fuscescens and three S. lineatus. Other $\delta^{13} \mathrm{C}$ and $\delta^{15} N$ values obtained from siganids collected at reef sites off Noumea $\left(22^{\circ} 14^{\prime} \mathrm{S} ; 166^{\circ} 28^{\prime} \mathrm{E}\right)$ were also used for species and habitat comparisons (Letourneur, unpublished data for 10 Siganus lineatus 186-209 mm TL; 5 S. punctatus 200-261 mm TL; 6 S. puellus 170-212 mm TL).

\section{Results}

The three Siganus randalli specimens exhibited the same meristic characters, body shape and color pattern as those described by Woodland (1990). Morphometric data are given in Table 1.

The stomach fullness values of S. randalli and S. lineatus caught in the mangrove was respectively $3.35 \pm 0.67$ and $3.42 \pm 0.57$. By comparison, low stomach fullness values of the two $S$. fuscescens $(0.43 \pm 0.03)$ showed lower feeding activity in the mangrove.

The diet of the $S$. randalli comprised 15 food items (Table 2). Rhodophyta and Phaeophyta were dominant in the stomach contents, which consisted mainly of Bostrychia sp. (75.6 \%), Dictyota sp. (10.7 \%) and Lomentaria sp. (4.2\%). This trend was also apparent in terms of \%W (67.2, 17.7 and $6.9 \%)$ and hence of

Table 1 Morphometric data of S. randalli, S. lineatus and S. fuscescens collected in Goro, New Caledonia

\begin{tabular}{|c|c|c|c|c|c|c|c|c|}
\hline \multirow[b]{2}{*}{$\mathrm{N}^{\circ} \mathrm{UNC}$} & \multicolumn{3}{|c|}{ S. randalli } & \multicolumn{3}{|c|}{ S. lineatus } & \multicolumn{2}{|c|}{ S. fuscescens } \\
\hline & Y1001 & Y1002 & Y1003 & Y1008 & Y1014 & Y1019 & Y1004 & Y1005 \\
\hline Weight (g) & 247.6 & 308.4 & 223.1 & 228.2 & 250.9 & 171.2 & 378.5 & 245 \\
\hline Total length (mm) & 240 & 253 & 231 & 235 & 237 & 212 & 306 & 274 \\
\hline Fork length (mm) & 220 & 235 & 213 & 217 & 220 & 197 & 278 & 246 \\
\hline Standard length (mm) & 178 & 189 & 170 & 174 & 177 & 186 & 232 & 201 \\
\hline Body depth (mm) & 95 & 101 & 90 & 92 & 92 & 85 & 100 & 85 \\
\hline
\end{tabular}


Table 2 Diet composition of S. randalli $(n=3)$, S. fuscescens $(n=2)$ and S. lineatus $(n=3)$ caught in Goro, New Caledonia, and expressed in frequency of occurrence (\%F), percent by number $(\% \mathrm{~N})$ and percent by weight $(\% \mathrm{~W})$. \%IRI: Percent of Index of Relative Importance

\begin{tabular}{|c|c|c|c|c|c|c|c|c|c|c|c|c|}
\hline \multirow[t]{2}{*}{ Items prey } & \multicolumn{4}{|c|}{ S. randalli } & \multicolumn{4}{|c|}{ S. lineatus } & \multicolumn{4}{|c|}{ S. fuscescens } \\
\hline & $\mathrm{F} \%$ & N\% & W\% & $\% \mid \mathrm{RI}$ & $\mathrm{F} \%$ & $\mathrm{~N} \%$ & W\% & $\%|R|$ & $\mathrm{F} \%$ & $\mathrm{~N} \%$ & W\% & $\%|R|$ \\
\hline \multicolumn{13}{|l|}{ Magnoliophyta } \\
\hline Halophila spp. & - & - & - & - & - & - & - & - & 50.0 & 1.0 & 2.8 & 1.5 \\
\hline Thalassia hemprichii & - & - & - & - & - & - & - & - & 100.0 & 5.7 & 8.3 & 11.5 \\
\hline \multicolumn{13}{|l|}{ Rhodophyta } \\
\hline Amphiroa sp. & - & - & - & - & - & - & - & - & 50.0 & 42.9 & 55.5 & 40.2 \\
\hline Bostrychia sp. & 100.0 & 75.6 & 67.2 & 74.2 & 100.0 & 49.0 & 44.6 & 62.0 & - & - & - & - \\
\hline Centroceras sp. & - & - & - & - & 25.0 & 0.1 & $<0.1$ & $<0.1$ & - & - & - & - \\
\hline Ceramiaceae spp. & 100.0 & 0.4 & 0.1 & 0.3 & 50.0 & 3.0 & 0.1 & 1.0 & 100.0 & 18.1 & 1.4 & 15.9 \\
\hline Ceramium spp. & - & - & - & - & 50.0 & 0.9 & 0.1 & 0.3 & - & - & - & - \\
\hline Gelidiella sp. & - & - & - & - & - & - & - & - & 50.0 & 17.1 & 18.5 & 14.6 \\
\hline Gelidium sp. & 66.7 & 3.7 & 3.8 & 2.6 & 50.0 & 0.7 & 0.4 & 0.4 & - & - & - & - \\
\hline Gracilaria sp. & - & - & - & - & 25.0 & 0.1 & 0.1 & $<0.1$ & - & - & - & - \\
\hline Hypnea spp. & - & - & - & - & 25.0 & $<0.1$ & 0.1 & $<0.1$ & 50.0 & 1.0 & 2.3 & 1.3 \\
\hline Hypoglossum sp. & 33.3 & $<0.1$ & 0.1 & $<0.1$ & - & - & - & - & - & - & - & - \\
\hline Lomentaria sp. & 100.0 & 4.2 & 6.9 & 5.7 & 100.0 & 4.6 & 6.4 & 7.3 & - & - & - & - \\
\hline Polysiphonia sp. & 66.7 & 1.1 & 1.8 & 1.0 & 50.0 & 9.0 & 16.1 & 8.3 & - & - & - & - \\
\hline Tolypiocladia sp. & - & - & - & - & 25.0 & 0.3 & 0.1 & 0.1 & - & - & - & - \\
\hline \multicolumn{13}{|l|}{ Chlorophyta } \\
\hline Caulerpa verticillata & 66.7 & 0.7 & 0.4 & 0.4 & 75.0 & 3.3 & 1.7 & 2.5 & - & - & - & - \\
\hline Chlorodesmis sp. & - & - & - & - & 25.0 & 6.0 & 10.7 & 2.8 & - & - & - & - \\
\hline Ulva sp. & - & - & - & - & - & - & - & - & 50.0 & 4.8 & 0.9 & 2.3 \\
\hline \multicolumn{13}{|l|}{ Phaeophyta } \\
\hline Padina sp. & 33.3 & 1.5 & 2.0 & 0.6 & 25.0 & 4.2 & 2.3 & 1.1 & - & - & - & - \\
\hline Dictyota sp. & 100.0 & 10.7 & 17.7 & 14.8 & 50.0 & 9.9 & 16.7 & 8.8 & - & - & - & - \\
\hline \multicolumn{13}{|l|}{ Invertebrates } \\
\hline Amphipods & 66.7 & 0.2 & 0.1 & 0.1 & 75.0 & 0.4 & 0.3 & 0.4 & - & - & - & - \\
\hline Ascidians & 33.3 & 0.3 & $<0.1$ & 0.1 & 25.0 & 0.1 & 0.1 & $<0.1$ & 50.0 & 2.9 & 3.8 & 2.7 \\
\hline Copepods & - & - & - & - & 75.0 & 0.5 & $<0.1$ & 0.2 & - & - & - & - \\
\hline Foraminiferans & 66.7 & 0.3 & $<0.1$ & 0.1 & 100.0 & 3.1 & $<0.1$ & 2.2 & 50.0 & 1.9 & $<0.1$ & 0.8 \\
\hline Halacarids & 33.3 & 0.5 & $<0.1$ & 0.1 & 25.0 & 0.2 & $<0.1$ & $<0.1$ & - & - & - & - \\
\hline Hydrozoans & - & - & - & - & - & - & - & - & 100.0 & 4.8 & 6.6 & 9.2 \\
\hline Isopods & - & - & - & - & 25.0 & 0.1 & $<0.1$ & $<0.1$ & - & - & - & - \\
\hline Diptera larvae & - & - & - & - & 25.0 & 0.4 & $<0.1$ & 0.1 & - & - & - & - \\
\hline Nematods & 33.3 & 0.5 & $<0.1$ & 0.1 & 100.0 & 3.3 & $<0.1$ & 2.2 & - & - & - & - \\
\hline Polychaetes & 33.3 & 0.3 & $<0.1$ & 0.1 & 75.0 & 0.8 & $<0.1$ & 0.4 & - & - & - & - \\
\hline
\end{tabular}

\%IRI (74.2, 14.8 and $5.7 \%)$. Consequently, niche breadth had a very low value $(B=0.05)$.

$S$. lineatus consumed more food items than $S$. randalli, but a similar trend occurred with regard to dominance of Rhodophyta and Phaeophyta. In accordance with \%IRI, the diet of S. lineatus was dominated by Bostrychia sp., Dictyota sp., Lomentaria sp. and Polysiphonia sp.
The niche breadth of this species also had a very low value $(B=0.07)$.

By contrast, only 10 items were found in the diet of $S$. fuscescens, again dominated by Rhodophyta, but also by Magnoliophyta and, to a lesser extent, Chlorophyta and invertebrates. The niche breadth of this species had a higher value than $S$. randalli and $S$. lineatus $(B=0.37)$. 
Table 3 Mean stable isotope ratios ( $\pm \mathrm{sd}) \delta 13 \mathrm{C}$ and $\delta 15 \mathrm{~N}$ of S. randalli, S. lineatus and S. fuscescens from mangrove, and of S. lineatus, S. punctatus and S. puellus from coral reef, New Caledonia

\begin{tabular}{|c|c|c|c|c|c|c|}
\hline \multirow[t]{2}{*}{ Species } & \multicolumn{3}{|c|}{ Mangrove } & \multicolumn{3}{|c|}{ Reef } \\
\hline & $\bar{N}$ & $\delta^{13} \mathrm{C}(\% 0)$ & $\delta^{15} \mathrm{~N}(\% 0)$ & $\bar{N}$ & $\delta^{13} \mathrm{C}(\% 0)$ & $\overline{\delta^{15} \mathrm{~N}(\% 0)}$ \\
\hline S. fuscescens & 2 & $-14.10 \pm 0.29$ & $7.00 \pm 0.34$ & - & - & - \\
\hline S. randalli & 3 & $-27.95 \pm 0.68$ & $5.67 \pm 0.21$ & - & - & - \\
\hline S. lineatus & 3 & $-26.13 \pm 1.50$ & $5.57 \pm 0.23$ & 10 & $-25.83 \pm 2.22$ & $5.06 \pm 1.03$ \\
\hline S. punctatus & - & - & - & 5 & $-14.91 \pm 1.10$ & $5.72 \pm 0.35$ \\
\hline S. puellus & - & - & - & 6 & $-16.42 \pm 1.97$ & $6.70 \pm 1.23$ \\
\hline
\end{tabular}

Strong niche overlap was found between $S$. randalli and $S$. lineatus $(O=0.99)$, but not between $S$. randalli and $S$. fuscescens $(O=0.01)$ or between $S$. fuscescens and $S$. lineatus $(O=0.01)$.

S. fuscescens has the most ${ }^{13} \mathrm{C}$-enriched and ${ }^{15} \mathrm{~N}$ enriched values, whereas $S$. randalli and $S$. lineatus from both habitats (mangrove and coral reef) exhibited quite similar values for $\delta^{13} \mathrm{C}$ and $\delta^{15} \mathrm{~N}$ (Table 3). Siganus punctatus and S. puellus had values similar to S. fuscescens for $\delta^{13} \mathrm{C}$, but their nitrogen isotopic signatures occupied a more intermediate position between $S$. fuscescens and $S$. lineatus from mangrove.

\section{Discussion}

The record of Siganus randalli from New Caledonian waters greatly extends its distribution, by approximately $1200 \mathrm{~km}$ southward and $1300 \mathrm{~km}$ southwest, compared to the closest previously recorded locations (i.e. the Solomon Islands and Fiji; Woodland 1990; Blaber et al. 1993). In view of the geographical distribution overlay (Woodland 1990) and the close phylogenetic similarities between S. lineatus and S. randalli (Borsa et al. 2007), this range extension is not surprising.

Apart from similar morphology characteristics, siganids can be separated into functional groups according to their feeding patterns. Siganus randalli revealed considerable differences from $S$. fuscescens in stomach content composition, a finding that explains the very low niche overlap for the two species. The close similarity found with $S$. lineatus in terms of stomach fullness, niche breadth and niche overlap suggests that $S$. randalli consumes the food resources of the mangrove in a comparable manner. Finally, the dominance of Bostrychia sp., a mangrove-associated algae (Zuccarello et al. 2006; Zuccarello and West 2008) in the diet of $S$. randalli highlights the importance of mangrove habitats for this species. Isotopic signatures support this view. Whereas S. fuscescens and S. puellus differ from $S$. randalli in their diets, functional groups (Debenay et al. 2011; Hoey et al. 2013) and hence their $\delta^{13} \mathrm{C}$ and $\delta^{15} \mathrm{~N}$, the mixed feeder $S$. punctatus revealed higher $\delta^{13} \mathrm{C}$, suggesting a diet of different origin. Siganus lineatus exhibits similar $\delta^{13} \mathrm{C}$ and $\delta^{15} \mathrm{~N}$ for both locations, suggesting that its diet has a single habitat origin. Most notably, similarities in the isotopic ratios between $S$. randalli and $S$. lineatus indicated a comparable resource origin, utilization and assimilation by these two species. This low or even negligible food partitioning between S. lineatus and S. randalli may indicate trophic competition in the mangrove habitat. Our observations need further confirmation because of the small number of individuals examined.

\section{Conclusion}

This note provides the most southerly record of the rabbitfish Siganus randalli. The data on its diet, when compared with other co-occurring or more reef-associated siganid species, provide information on feeding processes and ecological functions associated with its mangrove habitat. Several other specimens of $S$. randalli have been reported by fishermen, always in mangroves, in the northern part of New Caledonia, but individuals need to be captured to confirm these reports.

\section{Acknowledgements}

We warmly thank Germain Navarre Vama for allowing us to collect these specimens. We also thank Philippe Borsa and Gérard Mou-Tham for their valuable help.

\section{Funding}

This work was financially supported by Operation SIGA-NC, Zonéco Program, ADECAL Technopôle, New Caledonia.

\section{Availability of data and materials}

Siganus randalli specimens are available in the fish collection of the LIVE department, Université de la Nouvelle-Calédonie, catalogued as UNC-Y1001, UNC-Y1002 and UNC-Y1003.

\section{Authors' contribution}

TMo, LDP and YL carried out fieldwork; TMo and LDP analyzed the stomach contents; TMo and YL analyzed the isotopic signatures; TMo analyzed the data and wrote the manuscript; LDP, YL and TMe coordinated the study and corrected the draft manuscript. All authors read and approved the final manuscript.

\section{Competing interests}

The authors declare that they have no competing interests.

Consent for publication

Not applicable.

Ethics approval and consent to participate

The work was carried out under permit N²180-2013/ARR/DENV issued by DENV, South Province of New Caledonia. 


\section{Author details}

'Laboratoire LIVE et LABEX « Corail », Université de la Nouvelle-Calédonie, BP R4, Nouméa 98851, New Caledonia. ${ }^{2}$ Ifremer LEAD-NC, 101 Promenade Roger Laroque, Nouméa BP 2059, 98846, New Caledonia. ${ }^{3}$ UMR BOREA 7208, MNHN/CNRS/UPMC/IRD, 61 rue Buffon, Paris Cedex 5 CP 53, 75231, France.

${ }^{4}$ Aqualagon SARL, BP 2525 Mont-Dore, Nouméa 98800, New Caledonia.

Received: 22 August 2016 Accepted: 23 August 2016

\section{Published online: 15 September 2016}

\section{References}

Blaber SJM, Milton DA, Rawlinson NJF, Sesewa A. A checklist of fishes recorded by the Baitfish Research Project in Fiji from 1991 to 1993. Pages 102-110. In: Blaber SJM, Milton DA, Rawlinson NJF, Sesewa A, editors. Tuna Baitfish in Fiji and Solomon Islands: Proceedings of a workshop, Nadi, Fiji 17-18 August 1993, ACIAR Proceedings, 52. Canberra: Australian Centre for International Agricultural Research; 1993. http://trove.nla.gov.au/work/ 30776616? selectedversion=NBD1 1098819

Borsa P, Lemer S, Aurelle D. Patterns of lineage diversification in rabbitfishes. Mol Phylogenet Evol. 2007;44:427-35.

Brown JW, Chiricheti P, Crisostomo D. A cage culture trial of Siganus randalli in Guam. Asian Fish Sci. 1994;7:53-6.

Collins LA, Nelson SG. Effects of temperature on oxygen consumption, growth, and development of embryos and yolk-sac larvae of Siganus randalli (Pisces: Siganidae). Mar Biol. 1993;117:195-204.

Debenay JP, Sigura A, Justine JL. Foraminifera in the diet of coral reef fish from the lagoon of New Caledonia: Predation, digestion, dispersion. Rev Micropaleontol. 2011;54(2):87-103.

Fricke R, Kulbicki M, Wantiez L. Checklist of the fi shes of New Caledonia, and their distribution in the Southwest Pacific Ocean (Pisces). Stuttg Beitr Natkd Ser A. 2011;4:341-463. http://www.naturkundemuseum-bw.de/sites/default/ files/publikationen/serie-a/ns04-19frickekulbickiwantiez.pdf.

Galenzoga D, Quiñones G. Species Composition and Abundance of Marine Fishes in Selected Landing Areas of Northern Samar, Philippines. Pages 81-87. In: Rahman A, Ahmadi R, editors. International conference on Chemical, Environnement \& Biological Sciences Sept. 17-18, 2014, (CEBS-2014). Kuala Lumpur; 2014.

Hoey AS, Brandl SJ, Bellwood DR. Diet and cross-shelf distribution of rabbitfishes (f. Siganidae) on the northern Great Barrier Reef: Implications for ecosystem function. Coral Reefs. 2013;32:973-84.

Hurlbert SH. The measurement of niche overlap and some relatives. Ecology. 1978;59(1):67-77. http://onlinelibrary.wiley.com/doi/10.2307/1936632/abstract; jsessionid=59F6A092D7D0075EA2F5CDE71AEEE07D.f03t02

Kamikawa KT, Cruz E, Essington TE, Hospital J, Brodziak JKT, Branch TA. Lengthweight relationships for 85 fish species from Guam. J Appl Ichthyol. 2015;31: $1171-4$.

Nelson SG, Wilkins S. Growth and respiration of embryos and larvae of the rabbittish Siganus randalli (Pisces, Siganidae). J Fish Biol. 1994;44(3):513-25.

Pianka ER. Niche overlap and diffuse competition. Proc Natl Acad Sci. 1974;71(5): $2141-5$.

Pinkas L. Food habits study. Fish Bull. 1971;152:5-10.

Pinnegar JK, Polunin NVC. Differential fractionation of $\delta 13 \mathrm{C}$ and $\delta 15 \mathrm{~N}$ among fish tissues: implications for the study of trophic interactions. Funct Ecol. 1999; 13(2):225-31.

Randall JE, Kulbicki M. Siganus woodlandi, new species of rabbitfish (Siganidae) from New Caledonia. Cybium. 2005;29(1):185-9.

Woodland DJ. Revision of the fish family Siganidae with descriptions of two new species and comments on distribution and biology. Indo-Pac Fish. 1990;19:1-136.

Zuccarello GC, West JA. Bostrychia (Rhodomelaceae, Rhodophyta) species of New Zealand, and relationships in the Southern Hemisphere. N Z J Mar Freshw Res. 2008:42(3):315-24.

Zuccarello GC, West JA, Loiseaux-de-Goër S. Diversity of the Bostrychia radicans/ Bostrychia moritziana species complex (Rhodomelaceae, Rhodophyta) in the mangroves of New Caledonia. Cryptogam Algol. 2006;27(3):245-54.

\section{Submit your next manuscript to BioMed Central and we will help you at every step:}

- We accept pre-submission inquiries

- Our selector tool helps you to find the most relevant journal

- We provide round the clock customer support

- Convenient online submission

- Thorough peer review

- Inclusion in PubMed and all major indexing services

- Maximum visibility for your research

Submit your manuscript at www.biomedcentral.com/submit 